\title{
HISTORICAL SOCIOPRAGMATICS: A NEW APPROACH TO THE STUDY OF THE HISTORY OF HUNGARIAN*
}

\author{
ZSÓFIA SÁROSI
}

\begin{abstract}
The point of departure of this paper is that it is both timely and imperative to renew the traditional systemic approach to historical linguistics primarily focusing on Ancient Hungarian and Old Hungarian and supplement it with usage-centred research based on Middle Hungarian sources (like records of evidence in witchcraft trials). One possible way of doing that is offered by historical (socio)pragmatics, a line of study little known at present within Hungarian linguistics. Although a systematic application of (synchronically tried-and-true, all but classical) pragmatic theories and methods to historical material may come up against unforeseeable or even unresolvable difficulties, such "experimentation" is a promising enterprise: the pragmatic point of view and the theories built on it may provide historical investigations with a framework that can not only be expected to yield new conclusions but also to throw new light upon familiar facts of language history.

The title of this paper raises two questions: 1 . Is a new approach to the study of the history of Hungarian needed at all? and 2. What is historical sociopragmatics? In what follows, I will try to answer both questions in that order.
\end{abstract}

\section{Do we need a new approach?}

This question has been previously asked by several authors; I will briefly comment on their answers below. The reason why I begin by referring to Péter Maitz's recent paper (Maitz 2000) is that his way of asking this question, and his way of answering it, are rather similar to mine in a number of respects. Although he makes his particular claims with

* A version of this paper was presented as a talk in the Research Institute for Linguistics of the Hungarian Academy of Sciences, on 20 February, 2003. My study of historical sociopragmatics and hence the writing of this paper has been made possible by a visiting scholarship granted by the Institute for Linguistics between September 2002 and January 2003. I owe special thanks to Erzsébet Fehér, Lea Haader, Ferenc Pusztai and Andrea Ágnes Reményi: the conversations I had with them, their ideas, comments, and concurring as well as dissenting views have provided valuable help and feedback.

1216-8076/03/\$20.00 (C) 2003 Akadémiai Kiadó, Budapest 
reference to the history of the variety of German spoken by the German minority in Hungary, what he says is clearly relevant for the study of Hungarian historical linguistics as well. The differences between his paper and mine are that

(a) I focus on research on the history of Hungarian here and, being a linguist brought up on and working within the classical framework of Hungarian historical linguistics, I approach the issue from the angle of what is (for want of a better term) usually referred to as "traditional" linguistics;

(b) unlike Maitz, I do not pursue the aim of proposing a complex and comprehensive theory of historical linguistics. Rather, in addition to a rather sketchy overview of the state of the art, I wish to point out a gap and to highlight ways of bridging that gap, following some ideas put forward in the literature on other languages and using a few particular instances for exemplification.

\subsection{Hungarian historical linguistics, the "traditional" way}

I think that there are two basic questions in the history of linguistic changes (as in other areas of inquiry): how and why. Nevertheless, while the 'hows', i.e., questions concerning the course that those changes take, have continuously been receiving attempted answers in historical linguistics, the 'whys', i.e., queries into the reasons of linguistic changes, are only pursued as long as factors and relationships internal to the language system are able to provide some kind of explanation; beyond that, nothing tends to be explored as whatever is beyond language-internal considerations is said to be outside the competence of historical linguistics.

The question that József Herman asked 21 years ago is still an open one: "[...] does a causal explanation of changes in a language system fall within the scope of a realistically defined line of duty of historical linguistics?" (Herman 1982, 4). It appears that the present-day consensus among Hungarian historical linguists mainly shares his basically negative answer: "[...] the most important task continues to be an adequate and coherent exploration of facts, itself a creative type of activity" (ibid. 8).

The prevalent attitude in Hungarian historical linguistics is still dominantly system-centred: what is investigatied is primarily grammatical changes, i.e., changes in the system (phonology, morphology, syntax, semantics, word stock) of the language. This claim has been verified and 
its reasons within the history of linguistics have been analysed by several authors (e.g., Maitz 2000; Maitz-Molnár 2001; Juhász 2002), hence further support will not be adduced here.

The system-centred character of Hungarian linguistics naturally results in the fact that its focus of inquiry has been on the Ancient Hungarian and Old Hungarian periods, given that almost all interesting events (interesting, that is, with respect to the language system) took place then.

A third peculiarity of Hungarian historical linguistics that logically follows from the foregoing is that it exclusively studies written language or, more exactly speaking, a variety of the language that is particular to genres originally meant to serve written communication - as nothing else survived from the Old Hungarian period (and from Ancient Hungarian not even that).

Of course, the earlier literature also contained hints at 'extralinguistic' reasons for linguistic change. On the one hand, this is unavoidable if one deals with semantics, the word stock, etymology, or onomastics, for instance. On the other hand, larger, comprehensive surveys have always devoted some space to historical, social, cultural, etc. circumstances of, as well as their probable effects on, the people speaking the language and hence the language itself (a most obvious example of this is Bárczi 1963). But despite the fact that, e.g., Benkő (1988) deals with this aspect of historical changes more emphatically than it was usually done in earlier works, it is still within the realm of semantics and lexicology that the interdependence of linguistic changes and what are called their language-external reasons are mainly discussed. Phonology, morphology and syntax, highly important as they may be otherwise, are all but untouched in this respect. The terms themselves - "external" vs. "internal" history of a language - reinforce the impression that two clearly different things are involved, even if they may occasionally be loosely connected.

\subsection{Hungarian historical linguistics since the pragmatic turn}

The pragmatic turn in synchronic linguistics that has resulted in the birth of research trends approaching language from the direction of language use has not brought about a related breakthrough in historical linguistics. This is so even though, time and again, a wish of changing intensity to shift or enlarge the traditional approach towards a more sociolinguistically-oriented one has been sporadically expressed. A detailed review of these ideas would be out of place here, therefore I rest 
content with presenting, for illustration, some randomly chosen but perhaps characterisitc instances.

The article by Herman (1982) referred to above perambulated the question of whether the methods, results, and attitudes of sociolinguistics are applicable in historical linguistic studies. He then came to an essentially negative conclusion, embodied in his claim, cited above, concerning the most important task of historical linguistics.

A number of years later Klára Sándor, a practising sociolinguist, argued firmly and at many points conclusively that historical linguistics cannot afford to ignore the results of sociolinguistics and that it is pointless, in linguistic research that is at least aiming at comprehensiveness, to draw a sharp distinction between synchrony and diachrony, as well as, consequently, between the attitudes and methods applied in synchronic and diachronic studies, respectively (Sándor 1998a;b).

The historical linguist and dialectologist Dezső Juhász is rather more reserved when it comes to sociolinguistics. Referring back to Herman (1982), he raises the question "why should historical linguistics, having produced respectable results, be inspired by sociolinguistics, a promising but still very young discipline?" (Juhász 2002, 167). Yet, in the same paper, he refers to a "dimensional view" of language as a recommendable researcher's attitude. He uses that label for an approach to language "in which the three main dimensions of the operation of language, spatial, temporal, and human, form an organic unity" (ibid. 166). However, it appears that he formulates that merely as a theoretical desideratum: as far as practical work is concerned, what he thinks to be feasible is "a division of labour among the various branches of linguistics", adding that any linguistic description or explanation should involve "the possibility of being extended to all dimensions, even if it later turns out that the study of a certain dimension is irrelevant for the given subsystem or the problem at hand" (ibid.).

In the past few years, following some prompts from the international literature and - for the time being - as a theoretical possibility only, the notion of historical sociolinguistics has also emerged in the Hungarian literature.

Erzsébet Zelliger (Zelliger 1999; 2002), referring to Mattheier and Romaine, describes historical sociolinguistics as a discipline "whose range of interest is restricted to external history" $(2002,305)$. Its main task is to reconstruct historical changes in a way that "processes be explored within their social embedding" (ibid. 304). What this means more exactly turns 
out a few lines later: "What concerns the origin of particular linguistic phenomena, attention should be focused on circumstances that are related to the external history of the language. (Such are, e.g., language contacts, internal migration of the population, the structural layering of the society etc., and the effects of all these on lingustic changes, the modifications that take place in the individual linguistic subsystems.)" (ibid. 305).

What fails to be taken into consideration in this approach is the everyday communication of language users, the face-to-face interaction between speaker and listener, and the joint investigation of each particular linguistic phenomenon with its communicative context.

The first item of the Hungarian literature mentioning pragmatics alongside historical linguistics that I know of is Péter Maitz's article referred to at the very beginning of this paper. Maitz presents Mattheier's classification of the areas of historical linguistics; that classification already includes the sociopragmatic approach (Maitz 2000, 508). Maitz and Molnár (2001) follow up, mentioning the demand for a "sociopragmatic direction in historical linguistics". The authors approach the issue from the vantage point of textology (the subtitle of their article runs as "The role of texts and the tasks of textology in historical linguistics"). They take the central issue of historical text linguistics to be the types and kinds of texts, as well as their being determined by various factors. They discuss the problems of reconstructing and analysing oral communication in past ages and come to the conclusion that historical conversation analysis - that they take to be an adjoining field of study with respect to historical text linguitics - is a more or less Utopian enterprise (ibid. 333334 ). In spite of the fact that the grave difficulties that arise concerning historical sources and data are obvious to me as well, I do not share the authors' pessimistic view - I will return to this issue further below.

The studies briefly surveyed so far-both the ones dealing with researchers' attitudes and the ones actually discussing historical sociolinguistics - raise theoretical issues, and discuss theoretical considerations. The next question is, what happens in practice.

Although it becomes increasingly obvious for a number of reasons that within historical linguistics it is high time we turned to spoken language, hence to the Middle Hungarian and Early Modern Hungarian periods, that process is slow to get going.

As a continuation of $A$ historical grammar of the Hungarian language (Benkő et al. 1991; Benkő-Abaffy 1992; Benkő-Rácz 1995) large-scale 
research on Middle Hungarian is going on at the Historical Linguistics Department of the Research Institute for Linguistics of the Hungarian Academy of Sciences - but this, being a continuation of earlier work, focuses on the history of the language system just as much as the material published in previous volumes, even though, in view of the period it covers, it will probably include more substantial reference to characteristics of the spoken language.

Furthermore, there are some - albeit rather few-papers on spoken Middle Hungarian or some closely related variety of the language: Gergely (2002) and Pusztai (1999) are two recent examples. These papers, however, do not approach their topic on a sociopragmatic basis.

"Is this important at all?", the question may arise. An opinion shared by many, even including myself for a time, is "Why, we are doing practically the same thing as they are, except we are doing it with less ado and less theoretical garnishing" (where we refers to traditionalists and they refers to more pragmatically-oriented approaches). Is this really all there is to it?

At this point, it would be expedient to contrast two well-chosen excerpts from studies written on the same phenomenon of the history of Hungarian. One would be taken from a "traditional" system-oriented paper, whereas the other would exemplify the sociopragmatic approach. Their comparison would hopefully clearly show the differences between the two approaches. However, the point is exactly that papers of the latter, historical-sociopragmatic kind are, at present, completely missing from Hungarian historical linguistics. This is no wonder in view of the fact that we are at the stage of getting acquainted with that approach, rather new as it is in the international literature, too.

Given that it is far beyond the scope of the present paper to fill in that gap, I am forced to illustrate the potential differences on some asymmetrical examples.

First, I quote a characteristic passage from a non-pragmatically oriented, "traditional" paper (Sárosi 1984) that nevertheless investigates a language variety that is close to spoken language (personal letters) and focuses on the relationship between the participants of communication and its linguistic effects.

This longer paper (my own doctoral dissertation, as it happens) investigates terms of address (salutations) and ways people are referred to in 16th-century letters. The excerpt is taken from the chapter called Addressing vs. mentioning. The partners in correspondence are Pál Telegdy; 
his wife, Kata Várday; Anna Losonczy (Mrs Ugnot), a relative of Kata Várday's; and István Báthory who was also her relative and was on friendly terms with both her and her husband.

"The Telegdys had a protracted possessory action with Anna Losonczy: she had forcibly retained Kata Várday's pieces of property in Garan and Szentmárton that the Telegdys were unable to get back despite repeated efforts. One of these efforts is documented by letter 11, written by Pál Telegdy to his wife, asking her to copy a letter that he had written previously and to send it to Anna Losonczy. [...]

Neither Pál Telegdy, nor Kata Várday is particularly fond of Anna Losonczy - but now stakes are high and all the risks are on their side. Therefore, Telegdy has recourse to an age-old strategy that always does the trick: he "over-addresses" Anna Losonczy, using nagyságod "your Honour' or nagyságos 'Honourable' instead of kegyelmed 'your Worship' that she is entitled to. In the long and roundabout form of address all possible ways of influencing people can be found: nagyságod is a token of maximal social respect; but at least equally important is the family relationship, also respectfully emphasised ("nekem ßerelmes aßoniomnak nenemnek" 'to my beloved lady aunt'; we do not know how deliberate the order of social and kinship terms may have been in the 16th century in a form of address but this particular order in this particular letter cannot be a matter of mere chance). The construction szerelmes asszonyom néném of the form of address is immediately repeated as part of an appositiveaugmentative sequence introduced by mint 'as': "Szolgalatomat irom kdnek mint ßerelmes Aßoniomnak Nenemnek" 'allow me to express my deep respect to you as my beloved lady aunt'; in addition, two other forms replacing a personal pronoun are found in that elaborate formula. It is also characteristic that, whereas Pál Telegdy usually "expresses his thanks" in the introductory formulae of his letters to his wife, here Kata Várday is to "express her deep respect" (literally, her service) to her relative. $[\ldots]$

That age-old and never-failing trick of over-addressing puts the addressee into a higher social position than what she is actually entitled to. The effect is enhanced by the writer depicting herself as helpless, small, and exposed to danger. Pál Telegdy knows this and makes good use of it: "ne igjekezik ßeginj arua attiafiat meg niomoritanj" 'do not proceed to ruin your poor defenceless relative'. The letter closes on a tone of complete confidence but, to be on the safe side, Pál Telegdy composes a 
subservient formula to finish with: "Ngod ßeginj attiafia ßolgaloja Vardaj Kata" 'Your Honour's poor relative and servant Kata Várday'.

Its writers had high expectations of this [...] letter. Stages of hope and gradual loss of hope are clearly shown by the few references to Anna Losonczy that Pál Telegdy's covering letter and further letters contain. Letter 11 to Kata Várday mentions "Vgnotne aßoniom" 'My lady Mrs Ugnot' with confidence and full respect as befits her status and person. In letter 12, he still tells his wife not to be reluctant to call Anna Losonczy "your Honour", adding that once the possessory action is successfully over, she can call her whatever she likes. This letter is by far less respectful about "Ngos neü̈" 'the one with the honourable name' than the previous one but since their action is still pending, it is not offensive, either. Then, in letter 13, Pál Telegdy tells his wife that Anna Losonczy, in reply to their letter, sent armed men to their estates. Without knowing what the letter is about, the first (two-part) reference could be taken as reflecting a tender family relationship: "az mj ßerelmes atiankfia [...] Vgnotne aßoniom" 'our beloved relative [...] my lady Mrs Ugnot'. However, that reference is filled with anger and irony here. This restrained anger and embitterment erupts in the second reference of the same letter where Telegdy calls Mrs Ugnot "az hituan aßonj” 'that perfidious woman'.

When it comes to Anna Losonczy, István Báthory is even more vehement than Pál Telegdy is. He usually refers to his sister-in-law as "Vgnotné" 'Ugnot's wife', but often he does not even put down her name. The word asszony 'woman' was used in that period (among other uses) as a term of the highest esteem-Báthory uses that word referring to Mrs Ugnot twice, but both cases are filled with contempt and hatred in the actual context. Báthory loses his temper especially when he has to admit that he himself is powerless as against Anna Losonczy having duped his relatives: "igen alnak kuruane az" 'that one is a deceitful strumpet', "alnak kurua" 'deceitful whore', "cigani ez lotio" "this gypsy slut'. [...]

It is worth noting that although Báthory does write letters to Kata Várday about Anna Losonczy, he never uses indelicate words in these; hot-tempered words not fit for a lady are exclusively found in his letters to Pál Telegdy[...]" (Sárosi 1984, 132-7).

A historical sociopragmatic investigation of the same source would be conducted, among others, by using the following concepts and approaches: social roles and facework (Goffman 1955), words of power and solidarity (Brown-Gilman 1968), positive and negative politeness, face 
threatening acts (Brown-Levinson 1978), language use and social gender, implicatures, the theory of presuppositions, etc.

As another example, consider the following passage from Ferenc Pusztai's paper analysing spoken Middle Hungarian on the basis of records of evidence in witchcraft trials: interjections, modifiers and adverbs that occur in the records "use lexical means to give an idea of acoustic, intonational, etc. characteristics of spoken language (whose representation in writing continues to be difficult or incomplete in later periods, too).Separate and detailed documentation would also be required of the fact that such words (whether used by the prosecution or by the defence) often occur initially (or at least early) in an utterance as quoted in the records; thus serving as a "key signature", as it were, for what follows: the pejorative or ameliorative, conciliatory or offensive etc. tone of what is said. In that respect, they are close parallels of forms of address (and partly of forms of greeting), too. For instance: 1728: "amidőn a madarak csevegését hallotta, Rehu reájok pökdösvén mondotta nékik: - piha kutyák, hiába dicsíritek az istent, hiába, mert nem ad esőt, nem" "when she heard the twitter of birds, Rehu spat at them and said, "phooey you dogs, in vain do you praise God, in vain, he will not give rain, no"'; 1747: "Harmad nap múlván az Isten megadván a fatensnek az magzatot, mingyárt azon éjjel reáment a fatensre Gulyásné, az gyermekét akarta elvenni, mondván: - hoc ide, te kutya" 'Three days later, when God gave the child to the attestant, Mrs Gulyás rushed at the attestant that very same night wanting to take the child away, saying "chuck it across, you dog"'; 1729: "Varga Jánosné [...] mondja a fatensnek: - lelkem szomszéd asszony, ihon vagyon egy táska" 'János Varga's wife [...] tells the attestant, "listen, darling, here's a bag", etc." (Pusztai 1999, 382).

By developing the author's claims in terms of pragmatics, sociolinguistics, conversation and interaction analysis, not only would we get a more elaborated idea of the relationship between the italicised lexical items and forms of address/greeting as indicated in the quote but we could also reveal a historical aspect of discourse markers (expletive elements, particularizers), frequently studied in pragmatics-based synchronic terms but largely neglected so far in a diachronic perspective (at least within Hungarian historical linguistics).

In the papers we have looked at and in other similar papers, there are numerous observations on spoken language (or related varieties) that are in harmony with one another and complement one another in a number of ways - however, for lack of a broader perspective of interpretation 
that has not yet taken shape in the Hungarian literature, they remain unrelated pieces of evidence (even in spite of mutual cross-references), hence they are prone to be overlooked. It would be pity to lose sight of them altogether...

It is perhaps evident from these few and asymmetrical examples that two different approaches or paradigms are involved here.

1. One of them continues to be a system-centred view of a relatively new area of inquiry. The area is new because (a) the period investigated (Middle Hungarian) differs from that of previous studies; (b) the corpus studied is also different as new text types (e.g., protocols, records of evidence) are involved; consequently (c) the direction of research changes, too, in that more attention is devoted to phenomena of the spoken language. The investigation of context is also inevitably introduced but mainly as an illustrative interpretation of ("some extralinguistic reasons for") phenomena within the language system - the framework remains to be system-centred even if, due to the peculiarities of the topic studied, its scope for action is somewhat wider. Studies of a lexicological, semantic, or stylistic nature (that are relatively easier to accommodate in a system-centred overall framework) may now benefit from data on the circumstances of some communicative events that took place in the past, data that can be used more confidently for confirmation, interpretation and justification (in as much as such data do exist at all, unlike with respect to earlier periods).

2. The other-pragmatic - approach starts out from the functionality of language and explores the interface between language and language use, the systematic aspects of usage, given that language is realised in everyday verbal interactions and has a role not only in conveying information but also in creating social relationships in a community (that is, language use is a socio-communicative act). Thus a description and explanation of linguistic phenomena is unimaginable without approaching them from the direction of language use.

This is not merely a matter of shifting emphases: this is a completely distinct point of view that, once the linguist comes round to it, will make it impossible for her to ignore the influential theories and methodologies based on it that are employed in synchronic linguistics.

Two questions remain to be answered: 1 . Is it possible for researchers starting out from the two different directions to say the same things, to draw the same conclusions? 2. What is the most essential difference between the two approaches? 
I will return to these questions further below; let us now consider the other question that I raised at the beginning of this paper.

\section{What is historical sociopragmatics?}

Pragmatics itself is not easy to define. Kugler and Tolcsvai Nagy (2000), for instance, write that it is "a branch of linguistics that investigates the relationship between linguistic utterances (sentences, portions of texts) and speech situations". Andreas Jucker, whose papers-as well as the volumes (co)edited by him-will be referred to several times in what follows, defines pragmatics more generally as "the study of language in use" (Jucker 1995, ix). Jef Verschueren, on the other hand, claims that pragmatics is a "large, loose, and disorganized collection of research efforts" (cited in Jacobs-Jucker 1995, 3). It is certainly beyond my purpose here to go into terminological debates; therefore, even though the latter definition is perhaps a more telling description of the state of the art, I will base what follows on Jucker's definition (and, at various points, on his actual ideas). In particular, I will present the outlines of the discipline known as historical pragmatics/sociopragmatics on the basis of two recent collections of papers, Jucker (1995) and Jucker et al. (1999).

Jucker (1994) starts from contrastive pragmatics that compares linguistic and language-use characteristics of distinct languages and arrives at historical pragmatics that performs that comparison with respect to various historical periods of the same language.

I have to make a short terminological digression here. In this paper (as in its title) I often use the term historical sociopragmatics. This covers exactly the same ground as historical pragmatics does. The reason why I prefer the longer term with socio- in it is that I want to make clear where the place of this approach is within pragmatics. The whole discipline of pragmatics - including its historical aspects - is a relatively new and unsettled branch of linguistics, yet it has so many trends and so many terms for those trends that it may facilitate orientation if we point out that historical pragmatics, due to its historical-hence: empirical-perspective, belongs to what Leech $(1983,10-1)$ calls sociopragmatics or pragmalinguistics rather than to theoretical or general pragmatics (ibid. 10). That is, in what follows, historical pragmatics and historical sociopragmatics mean the same thing: the study of the relationship between language and language use in a historical perspective, with special emphasis on interactions of two or more participants and the contexts of those interactions. 


\subsection{The nature of historical pragmatics}

One of the volumes referred to above (Jucker et al. 1999) bears the title Historical dialogue analysis. This is not the name of yet another discipline but rather the same as historical pragmatics - with its contents made more specific. The editors make this clear right at the beginning of their introductory paper saying that essentially all language use goes on in dialogues since speakers or writers use language in order to communicate with an actual, a potential, or an imaginary addressee (ibid. 1). Although this is a rather loose interpretation of the notion of dialogue, there being quite a difference between a text that can only be called a dialogue in a rather indirect sense and an actual interaction - for instance, between a will and a judge-witness dialogue at a witchcraft trial-, it goes without saying that such an approach may open up new vistas in historical linguistics where it has hardly ever been taken, if at all.

In their introduction to Jucker (1995), Jacobs and Jucker make an attempt to capture the essence of historical pragmatics. The fact that this is no easy task (and that this discipline can be approached from a number of angles) is demonstrated by the abundance of terms occurring in the first four pages of the introduction: historical pragmatics, diachronic pragmatics, pragmatic historical linguistics, historical linguistic pragmatics, pragmatic perspective to historical linguistics, pragmahistorical linguistics, pragmahistorical linguistic perspective, historical dimension to pragmatics, historical pragmatic perspective, pragmaphilology. This bewildering proliferation is not as bad as it seems, though, if we consider the fact that this is a young area of study still trying to find its place and identity.

In fact, then, historical pragmatics includes both historical linguistics employing the point of view and methods of pragmatics and pragmatics submerged in historicity as a new dimension - these two paths differ in their point of departure and in where the emphases are put during the investigation but eventually lead to one and the same point. In particular, "Historical pragmatics deals with changes in the linguistic structure resulting from altered communicative needs which are due to changes in the social structure" (Jacobs-Jucker 1995, 6). 


\subsection{The place of pragmatics within a complex historical investigation of language}

This is still a rather general formulation. One possible way of making it more precise is to find the place of historical pragmatics within the historical study of language; this can be done as in Mattheier's model, referred to above (cf. Maitz 2000, 507-8).

Archer and Culpeper (2003) see the differences of pragmatics, sociolinguistics, historical linguistics, and corpus linguistics as follows. Pragmatics traditionally studies language use in context, whereas sociolinguistics is primarily interested in language variation and the relationship between a language and the community that speaks it, paying less attention to the dynamic interaction of language and context. The focus of historical linguistics, in turn, is on reconstructed linguistic forms. Finally, corpus linguistics concentrates on text and co-text, as well as relationships between linguistic forms as in collocations, for instance.

It is perhaps worth trying to formulate what in my view is the essence of historical sociopragmatics as seen from the point of view of traditional historical linguistics - using, for the time being, the not-quite-felicitous terms external vs. internal.

If we maintain that the history of the system of a language is the subject-matter of "internal" historical linguistics and the cultural, historical, social influences that the speech community is exposed to, including the mutual influence of several communities of speakers on one another, constitute "external" historical linguistics, then historical (socio)pragmatics is whatever there is between the two. This discipline studies the everyday verbal interaction of speakers - in the case of historical linguistics, this of course means "written spoken language" (Ferenc Pusztai's term) - and traces how the linguistic system and the factors determining language use converge and are realised in the language user, how these interact and work together. That is, optimally, it includes both "external" and "internal" historical linguistics - and in exactly the way they are related in real life: embedded in the everyday practice of communicating parties, in an organic unity.

\subsection{Areas of application}

Where and how historical pragmatics can be put to use includes the following areas. 
Somewhat different from an explicitly linguistic-pragmatic investigation of texts is what is called pragmaphilology, studying the context of historical texts (documents): this includes the function and aim of a text, the physical and social background and ways of producing and perceiving it; as well as the exploration of the speaker's and the addressee's circumstances of life, social status and personal relationship. (Consider the following titles of contributions from Jucker (1995): "Punctuation: and-'pragmatics'"; "Wills and will-making in 16th and 17th century England: Some pragmatic aspects".)

Linguistic-pragmatic studies fall into two groups that are often not so easy to distinguish in terms of whether their point of departure is linguistic form or function. The former type, known as form-to-function mapping, can start from relative pronouns, lexical items, or discourse markers, i.e., from various grammatical categories that constitute the basis of comparison, and end up with their period-dependent pragmatic functions. (Examples: "Pragmatic constraints to word order and word order change in English"; "Diachronic analysis of Japanese discourse markers".)

The latter approach, function-to-form mapping, on the other hand, can start from a specific speech act or, say, the concept of politeness, use these as the basis of comparison, and have the aim of exploring diverse ways of fulfilling those functions (often grammatical ones, e.g., the use of pronouns) in a diachronic perspective. (Examples: "Linguistic politeness strategies in Shakespeare's plays"; "Discourse strategies in Early Modern English travelogues"; "Constraints on politeness: The pragmatics of address formulae in early English correspondence".)

Of course, whichever perspective is taken, it may turn out to be the case that form and function both undergo changes in time - therefore, it is not possible to draw a sharp dividing line between the two approaches.

\subsection{Possibilities of merging the history of the language system with pragmatics}

How can the history of the language system (or grammar) and the study of the everyday "natural workings" of language be coupled in actual historical sociopragmatic research?

Whether we consider form-to-function or function-to-form studies in historical pragamatics, the language system has an important role in both: either as a point of departure or as a destination, any level of the system, down to morphemes, may be the focus of investigation. Explo- 
ration of and familiarity with the language system is a sine qua non of further research. Usage-based approaches may of course classify linguistic items in a way that does not correspond to traditional part-of-speech categories: for instance, the class of discourse markers includes modifiers, adverbs, conjunctions, interjections, verbs, etc.- -but it is exactly such flexible regroupings and the conclusions that can be drawn from them that may provide us with new possibilities of interpretation. That is, a question that has but rarely been raised so far emerges as a fundamental issue: How do the changes of grammatical structure depend on and bear upon pragmatic factors?

In sum, the history of the system and the history of language use cannot do without one another-they are built upon and built into one another, each helps us make sense of the other.

\subsection{Sources and data}

The most problematic issue in historical sociopragmatics is that of data. First of all: what counts as a source?

Most researchers studying historical aspects of language use do not regard written documents as imperfect imitations of "real" - i.e., spokenlanguage but rather as "stand-alone" embodiments of communication. Thus, they take the subject-matter of pragmatic investigation to include not only witnesses' testimonies and (especially private) letters but also plays and other works of fiction, wills, old grammar books, manuals of etiquette, conversation guides and foreign-language textbooks.

Synchronic pragmatics deals primarily with spoken language. The student of historical pragmatics, on the contrary, cannot rely on anything but written sources. Although that fact doubtlessly puts her into a disadvantageous position as compared to synchronic linguists, the situation is not as hopeless as it might seem from what Péter Maitz and Anna Molnár write about it: "[...] absolutely none of oral communication or its texts survived in their original form" (Maitz-Molnár 2001, 333); and "[...] all we may get to know about the history of conversation can only be based on an analysis of the few types of conversation, not even prototypical ones (e.g., dramatic dialogues, parliamentary debates), that have been committed to writing for some reason (like their intention, their predictable significance, etc.)" (ibid. 334). Strangely enough, the authors do not even mention minutes of the court or records of evidence - even though, for instance, talking of records of evidence in medieval witchcraft 
trials, "We can say that some of the records appear to be so authentic and directly corresponding to the spoken words of the witness to such an extent that we could refer to them as 'spoken language (put down in writing)' rather than written language (that preserves some features of spoken language)" (Pusztai 1999, 358). Of course, no matter how lifelike these texts are, several factors (like the writer of the record whointentionally or unintentionally but - necessarily "filters" what has been said) make it impossible for them to be a match for present-day data based on video recordings and published in the form of transcripts - but such equivalence is not required, either. It is clear that some components of modern conversation analysis and the completeness of the picture it is able to provide have to be automatically given up by someone who studies historical sociopragmatics. Nevertheless, it is by no means a Utopian enterprise in my view to obtain a substantial body of knowledge about the oral communication of the Middle Hungarian period, for instance; that knowledge may be incomplete but will be necessarily and significantly more extended than what we have today. (In that respect, metalinguistic and metapragmatic hints and remarks that are often found, especially in records of lawsuits, will be of great help to the researcher.)

Another problem is how to ascertain the situational context of the text we are studying as it is usually but meagre data that we have in that respect. Collecting as many, as exact and as detailed data about the context as possible is a demanding task but not a hopeless one, even in the case of historical materials. For instance, electronic corpora are available even of relatively early periods of English. Although the compilation of a similar corpus for Hungarian is not more than a matter of hope today, a number of the methods invented for electronic data management can be replicated manually, too; therefore it is worth looking at some of them.

Archer and Culpeper (2003) present a computer program of sociopragmatic annotation that handles not only traditional sociolinguistic variables like age, gender, and social status, but also introduces the category of pragmatic role. They treat speaker-related and addressee-related data with equal emphasis. Since they work with historical material, they define categories like 'social status' in a way that reflects the general notions and beliefs of contemporary observers, the actual situation of the period.

In determining a person's age, for instance, they take the milestones of an average course of life in the Early Modern English period into account. Thus, they rely on the time of first marriage (cca. mid- 
twenties) or the time of some important turn in a person's career (e.g., judicial appointment - this could not have happened before the person turned middle-aged), etc. They also make the category of 'role' more detailed than usual, distinguishing activity roles (like 'witness'), kinship roles (like 'wife'), social roles (like 'servant'), and dramatic roles (like 'seducer'). They insist that during the investigation - with the help of their annotation - the interaction between speaker and addressee(s) should be traceable "utterance by utterance".

In sum, it is certain (and demonstrated by actual studies) that speech acts, discourse markers, politeness phenomena (including facework), implicatures and presuppositions, the issue of the cooperative principle, etc. can be studied on a historical material, too.

\section{Does historical sociopragmatics give us more than system-oriented historical linguistics does?}

We have good reasons to assume that the study of language use will throw new light upon the history of grammatical changes or, more broadly, of changes in the system of a language. It is likely that in a number of matters (of historical morphology, historical syntax, etc.) we will come closer to possible (possibly correct) answers. This can be expected to happen, for instance, with respect to an in-depth interpretation of the statistics of occurrence/frequency that are also included in A historical grammar of the Hungarian language (Benkő et al. 1991; Benkö-Abaffy 1992; Benkő-Rácz 1995).

It is an old problem often referred to that we know next to nothing about the spoken language - the genuine language, to put it that way — of earlier ages (like Old Hungarian). This is because our claims concerning Old Hungarian are almost exclusively based on texts that were directly meant to be instances of written language. We only guess that this might differ considerably from the spoken language of the period as used by large masses of speakers. The gravity of this problem is certainly alleviated by what Ferenc Pusztai puts as follows: "Of course, spoken-language phenomena that can be pinned down in Middle Hungarian documents are to be projected back to earlier synchronic stages of the language since it is beyond reasonable doubt that most of these did not come into being in that period. Rather, it was only then that they found their way, 
in large numbers and variety, to written documents whose text type (e.g., record of evidence) made this possible" (Pusztai 1999, 381).

In view of the foregoing, and specifically of what is widely known as the "uniformitarian principle" (see, e.g., Romaine 1982, 122; Sándor 1998b, 66) - saying that linguistic changes in the past must have proceeded just like present-day ongoing changes do, except that the latter can be clearly observed and described, hence it is perfectly legitimate to use the analogy of claims and conclusions of synchronic sociolinguistics for understanding historical change - no further explanation is needed with respect to why historical sociopragmatics may open up promising new vistas in historical linguistics as a whole.

As was pointed out at the beginning of this paper, I do share the view that the competence of historical linguistics by all means includes looking for reasons and explanations - just like in the case of the human body and mind, it is also in human language that "everything is connected to everything else".

After all, what is the most essential difference between studies of Middle Hungarian spoken language that are based on a systemic approach and those based on pragmatic considerations?

The former may go some way in asking why things are the way they are but then they stop doing that at a point where further inquiry would force them to leave the realm of system-bound issues. In order to be able to continue to ask such questions, they would have to assume a different point of view, a different way of looking at things. Let me add here two little examples taken from a paper on letters written by $16-17$ thcentury politicians: "the communicative situation (who writes to whom) can be seen to influence the use of phrasemes"; and-writing about the use of milder terms of abuse - "phraseology involving $e b$ 'dog' seems to have been in use indiscriminately, irrespective of who the writer or the addressee was" (Gergely 2002, 195-6). Both statements would naturally be followed by asking why this is so-but in a paper whose approach is basically non-pragmatic, neither asking the question nor trying to find an answer would be consistent with the author's intentions.

If we adopt a pragmatic perspective in our research on the history of a language, we can more confidently ask questions beginning with 'why', simply because we stand a better chance of getting closer to the answer than in a purely systemic or a purely "external" approach. Klára Sándor paraphrases Labov saying that "our results are necessarily distorted if we try to analyse a linguistic phenomenon in two parts: the sum of results 
yielded by "external" and by "internal" linguistics do not add up to be equivalent to results that a linguist arrives at by studying language in its natural course of operation" (Sándor 1998a, 58).

One more question remains to be answered. When it comes to the historical investigation of spoken language, do representatives of the two different paradigms, the system-oriented and the pragmatics-based ones, really say the same things or come to the same conclusions -indeed, is it possible for them to say the same things, come to the same conclusions, or reveal the same potential consequences, despite the fact that their points of departure and their methods are not the same?

This is a real issue, and an open one. Research on Middle and Early Modern Hungarian spoken language either that of the type rooted in the traditions of Hungarian historical linguistics and based on a systemic approach, or that of the relatively more recent type in terms of historical sociopragmatics - has not yet produced a sufficient amount of actual results for us to be able to give a well-founded answer to that question (the former type has produced precious little, while the latter, as far as I know, none at all).

I can only speculate that research starting from those two directions will probably not arrive at the same point. If one starts exploring an essentially functional issue, using pragmatics as a theoretical and practical basis, then one knows and accepts from the very start that one's current problem is part of the network of correspondences that - since the "turn", i.e., over the past 30-40 years - synchronic pragmatics has revealed and substantiated concerning language use. That embeddedness of a problem to be explored makes it possible for us to draw conclusions that are not better or worse than the ones that can be drawn in terms of the traditional systemic approach: they are simply different.

My answer to the question raised at the beginning of this paperof whether a new approach to the study of the history of Hungarian is needed - is in the positive. But what I have in mind is not a change of perspective: it is an additional angle to view things from. The more so since I think that historical pragmatics would - or could - mean just that. That is: it should not mean adopting a trendy new discipline and discarding the old one but rather a great new chance. The chance of unrestricted traffic, going to and fro, between two paradigms, two approaches to linguistics.

This is obviously a matter of one's view of what linguistics is all about. What is more important for us: keeping our paradigms or ap- 
proaches "uncontaminated", that is, using them consistently and in an exclusive manner; or else the questions we may ask one after the other that open up new perspectives and carry us over to new schools of thoughteven if this entails a certain mix-up of viewpoints and aspects, and we cannot be sure if that mix-up would lead us to chaos or rather to a new order?

In the present age of interdisciplinarity this may sound like a simpleminded or belated query; but as far as I can see, it is not. Linguistics struggles with the embarrassing contradiction that, on the one hand, being a branch of science, it appreciates fair, thorough, and objective exploration as well as clear, consistent, and unambiguous argumentation more than anything else; but on the other hand, its subject-matter is a complex, (on a common-sense level) inconsistent, rarely if ever clear-cut (or clearly interpretable) human facility: language. Thus, we often find ourselves in a fairly grotesque situation: each school of linguistics "keeps telling its own story", consistently using its own technical parlance that differs from everybody else's, while the various parties sometimes fail to understand what the others are saying and the outsider does not realise that they all speak about the same thing, after all, except they approach it from diverse directions. In this respect, a really satisfactory solution will probably not become available as long as it is more important for us to stick to a reassuring unanimity and consistency coming from our steady and exclusive application of the tools of our own paradigm than to admit that our single and common subject-matter, human language, is anything but clear and unanimous and that we will never come close to "explaining" it if we insist on a single point of view - indeed there is no paradigm of linguistics that would be able to embrace the whole network of connections that, taken together, define human language.

What I think is important is the question we ask about language and language use (that are organically bound up with one another), in order to get as far as possible in answering it. To be able to do that, the researcher who wants to keep asking 'why' and who is familiar with and feels comfortable in both paradigms, will employ exactly the tools taken from either, or indeed any combination of tools taken from both, that help her in the particular task she is working on and make it possible for her to achieve the aim of it all: the deepest possible understanding of the given problem. 


\section{References}

Archer, Dawn - Jonathan Culpeper 2003. Sociopragmatic annotation: New directions and possibilities in historical corpus linguistics. In: Andrew Wilson-Paul Rayson - Tony McEnery (eds): Corpus linguistics by the lune: A Festschrift for Geoffrey Leech, 37-58. Peter Lang, Frankfurt am Main.

Bárczi, Géza 1963. A magyar nyelv életrajza [The biography of the Hungarian language]. Gondolat Kiadó, Budapest.

Benkő, Loránd 1988. A történeti nyelvtudomány alapjai [Fundamentals of historical linguistics]. Tankönyvkiadó, Budapest.

Benkő, Loránd-Erzsébet E. Abaffy-Endre Rácz (eds) 1991. A magyar nyelv történeti nyelvtana. 1. kötet: A korai ómagyar kor és előzményei [A historical grammar of Hungarian. Volume 1: Early Old Hungarian and its antecedents]. Akadémiai Kiadó, Budapest.

Benkő, Loránd-Erzsébet E. Abaffy (eds) 1992. A magyar nyelv történeti nyelvtana. 2/1. kötet: A kései ómagyar kor: morfematika [A historical grammar of Hungarian. Volume 2/1: Late Old Hungarian: morphematics]. Akadémiai Kiadó, Budapest.

Benkő, Loránd-Endre Rácz (eds) 1995. A magyar nyelv történeti nyelvtana. 2/2. kötet: A kései ómagyar kor: mondattan, szöveggrammatika [A historical grammar of Hungarian. Volume 2/2: Late Old Hungarian: syntax, text grammar]. Akadémiai Kiadó, Budapest.

Brown, Penelope - Stephen Levinson 1978. Universals in language usage: politeness phenomena. In: Esther N. Goody (ed.): Questions and politeness: strategies in social interaction, 56-289. Cambridge University Press, Cambridge.

Brown, Roger - Albert Gilman 1968. The pronouns of power and solidarity. In: Joshua A. Fishman (ed.): Readings in the sociology of language, 252-275. Mouton, The Hague.

Gergely, Piroska B. 2002. A közéleti és a beszélt nyelv viszonya az erdélyi fejedelemségben [Public vs. private language in the Principality of Transylvania]. In: Hoffmann et al. (2002, 31-115).

Goffman, Erving 1955. On face-work. In: Psychiatry 18:213-231.

Herman, József 1982. Szociolingvisztika és nyelvtörténet [sociolinguistics and historical linguistics]. In: Magyar Nyelv 78:1-8.

Hoffmann, István - Dezső Juhász - János Péntek (eds) 2002. Hungarológia és dimenzionális nyelvszemlélet. Előadások az V. Nemzetközi Hungarológiai Kongresszuson [Hungarology and a dimensional view of language. Papers presented at the Fifth International Congress of Hungarology]. Debrecen \& Jyväskylä.

Jacobs, Andreas - Andreas H. Jucker 1995. The historical perspective in pragmatics. In: Jucker (1995, 3-33).

Jucker, Andreas H. 1994. The feasibility of historical pragmatics. In: Journal of Pragmatics $22: 529-547$.

Jucker, Andreas H. (ed.) 1995. Historical pragmatics. Pragmatic development in the history of English. John Benjamins, Amsterdam \& Philadelphia. 
Jucker, Andreas H.-Gerd Fritz - Franz Lebsanft (eds) 1999. Historical dialogue analysis. John Benjamins, Amsterdam \& Philadelphia.

Juhász, Dezső 2002. Magyar nyelvjárástörténet és történeti szociolingvisztika: tudományszemléleti kérdések [Hungarian historical dialectology and historical sociolinguistics: issues of scholarly attitudes]. In: Hoffmann et al. (2002, 165-72).

Kugler, Nóra-Gábor Tolcsvai Nagy 2000. Nyelvi fogalmak kisszótára [A pocket dictionary of linguistics]. Korona Kiadó, Budapest.

Leech, Geoffrey N. 1983. Principles of pragmatics. Longman, Harlow.

Maitz, Péter 2000. A nyelvtörténetírás elvi kívánalmairól a német nyelv magyarországi története kapcsán [On some desiderata of principle in historical linguistics, with respect to the history of German in Hungary]. In: Magyar Nyelvőr 124 : 501-513.

Maitz, Péter-Anna Molnár 2001. Nyelvtörténetírás és történeti szövegnyelvészet [Historical linguistics and historical text linguistics]. In: Péter Csatár-Péter MaitzKrisztián Tronka (eds): A nyelvtantól a szövegtanig. Tanulmányok Kocsány Piroska tiszteletére [From grammar to textology. Papers in honour of Piroska Kocsány], 322-35. Kossuth Egyetemi Kiadó, Debrecen.

Pusztai, Ferenc 1999. Beszélt nyelv a középmagyarban [Spoken Middle Hungarian]. In: Névtani Értesítő $21: 380-6$.

Romaine, Susan 1982. Socio-historical linguistics. Cambridge University Press, Cambridge.

Sándor, Klára 1998a. Amiért a szinkrón elemzés foszladozik [Why synchronic analysis frays]. In: Klára Sándor (ed.): Nyelvi változó - nyelvi változás [Linguistic variables and linguistic change], 57-84. JGyF Kiadó, Szeged.

Sándor, Klára 1998b. A magyar-török kétnyelvüség és ami körülötte van [HungarianTurkish bilingualism and what is around it]. In: István Lanstyák-Gizella Szentmihályi (eds): Nyelvi érintkezések a Kárpát-medencében [Language contacts in the Carpathian Basin], 7-26. Kalligram Könyvkiadó, Pozsony (Bratislava).

Sárosi, Zsófia 1984. Magyar nyelvủ megszólítás és említés XVI. századi misszilisekben [Hungarian forms of address and names mentioned in 16th-century letters]. Doctoral dissertation, ELTE, Budapest.

Zelliger, Erzsébet 1999. Gondolatok a magyar nyelvtörténet szociolingvisztikai szempontú megközelítéséhez [Remarks on a sociolinguistic approach to Hungarian historical linguistics]. In: Magyar Nyelvjárások 38 :505-12.

Zelliger, Erzsébet 2002. A történeti szociolingvisztika egyetemi oktatása [Historical sociolinguistics as a university course]. In: Hoffmann et al. (2002, 303-7).

Address of the author: Zsófia Sárosi

Department of Hungarian Historical Linguistics,

Sociolinguistics, Dialectology

Eötvös Loránd University

Múzeum krt. 4/A.

H-1088 Budapest

Hungary

sarosi@ludens.elte.hu

Acta Linguistica Hungarica 50, 2003 